\title{
Pengaruh Budaya Organisasi dan Motivasi Kerja Terhadap Kinerja Pegawai Yayasan Dompet Dhuafa Jakarta
}

\author{
A.Rafiq \\ Universitas Bina Sarana Informatika \\ Email: rafiq.afq@bsi.ac.id
}

\begin{abstract}
Cara Sitasi: Rafiq, A. (2019). Pengaruh Budaya Organisasi dan Motivasi Kerja Terhadap Kinerja Pegawai Yayasan Dompet Dhuafa Jakarta. Widya Cipta, 3(1), 105-114.
\end{abstract}

\begin{abstract}
This study aims to analyze the Effect of Organizational Culture and Work Motivation on the Employee Performance of the Dompet Dhuafa Republika Foundation in Jakarta. The method used is Multiple Linear Regression analysis where it is assumed that the variable Organizational Culture and Work Motivation has an influence on the Employee Performance of the Dompet Dhuafa Republika Foundation in Jakarta. The results obtained state that Organizational Culture and Work Motivation have an influence on employee performance by $54.2 \%$. Organizational Culture Variables have a dominant influence on employee performance. From the results of the study, it is expected that in the future, the application of organizational culture will be further enhanced so that it is truly pervasive and imbued by every individual in the dhuafa wallet. In addition, it is necessary to develop employees in the form of rewards and clear rewards, both in the form of material rewards and career advancements and increasing knowledge in accordance with employee achievements to generate high motivation from their employees.
\end{abstract}

Keywords: Organizational Culture, Work Motivation, Employee Performance.

\section{PENDAHULUAN}

Suatu yayasan atau lembaga didirikan karena mempunyai tujuan yang ingin dicapai. Dalam mencapai tujuannya setiap yayasan atau lembaga dipengaruhi oleh perilaku dan sikap orang-orang yang terdapat dalam yayasan atau lembaga tersebut. Keberhasilan untuk mencapai tujuan tersebut tergantung kepada keandalan dan kemampuan pegawai dalam mengoperasikan unit-unit kerja yang terdapat di yayasan atau lembaga tersebut, karena tujuan yayasan atau lembaga dapat tercapai hanya dimungkinkan karena upaya para pelaku yang terdapat dalam setiap yayasan atau lembaga.

Organisasi merupakan suatu sistem yang saling mempengaruhi satu sama lain, apabila salah satu dari sub sistem tersebut rusak, maka akan mempengaruhi sub-sub sistem yang lain. Sistem tersebut dapat berjalan dengan semestinya jika individu-individu yang ada di dalamnya berkewajiban mengaturnya, yang berarti selama anggota atau individunya masih suka dan melaksanakan tanggung jawab sebagaimana mestinya maka organisasi tersebut akan berjalan dengan baik.

Sumber Daya Manusia (pegawai) merupakan unsur yang strategis dalam menentukan sehat tidaknya suatu organisasi. Pengembangan SDM yang terencana dan berkelanjutan merupakan kebutuhan yang mutlak terutama untuk masa depan organisasi. Dalam kondisi lingkungan tersebut, manajemen dituntut untuk mengembangkan cara baru untuk mempertahankan pegawai pada produktifitas tinggi serta mengembangkan potensinya agar memberikan kontribusi maksimal pada organisasi. Masalah sumber daya manusia yang kelihatannya hanya merupakan masalah intern dari suatu organisasi sesungguhnya mempunyai hubungan yang erat dengan masyarakat luas sebagai pelayanan publik yang diukur dari kinerja.

Manajemen sumber daya manusia merupakan sarana untuk meningkatkan kualitas manusia, dengan memperbaiki sumber daya manusia, meningkatkan pula kinerja dan daya hasil organisasi, sehingga dapat mewujudkan pegawai yang memiliki disiplin dan kinerja yang tinggi sehingga diperlukan pula peran yang besar dari pimpinan organisasi.

Selain itu, para ahli dan praktisi manajemen telah mengakui bahwa sumber daya manusia dalam organisasi merupakan faktor sentral yang perlu mendapat perhatian. Dalam paradigma masa kini, sumber daya manusia yang bekerja dalam perusahaan adalah merupakan kekayaan (asset) dan salah satu sumber keunggulan kompetitif dan elemen kunci yang penting untuk meraih kesuksesan dalam bersaing dan mencapai tujuan. Untuk itu 
sumber daya manusia perlu dikembangkan dan diperhatikan agar kualitas sumber daya manusia tersebut dapat ditingkatkan, sehingga berdampak pada meningkatnya kinerja organisasi (perusahaan) di mana sumber daya manusia tersebut berada.

Sesungguhnya, tujuan utama perusahaan adalah untuk mencapai laba maksimum, agar tujuan perusahaan dapat tercapai maka perusahaan harus mempunyai kinerja yang tinggi. Kebijaksanaan perusahaan mempunyai pengaruh yang kuat terhadap kinerja karyawan dalam melakukan kegiatan perusahaan. Oleh karena itu perusahaan harus dapat menentukan suasana dalam membentuk iklim perusahaan yang baik, sehingga membawa dampak pada kinerja yang tinggi pula.

Kinerja karyawan merupakan salah satu faktor penting dalam kemajuan suatu perusahaan. Kinerja karyawan menjadi sangat penting karena penurunan kinerja baik individu maupun kelompok dalam suatu perusahaan dapat memberi dampak yang berarti dalam suatu perusahaan. Sehingga dalam hal ini seorang manajer memiliki tugas yang cukup berat di mana dia harus selalu berusaha meningkatkan kinerjanya dan memberi motivasi bagi bawahannya agar dapat meningkatkan kinerja mereka untuk mencapai tujuan perusahaan.

(Prawirosentono, 2008) kinerja adalah hasil kerja yang dapat dicapai oleh seseorang atau kelompok dalam suatu organisasi sesuai dengan wewenang dan tanggung jawab masing-masing, dalam rangka upaya mencapai tujuan organisasi bersangkutan secara legal, tidak melanggar hukum dan sesuai dengan moral dan etika. Kinerja individu akan berpengaruh terhadap kinerja perusahaan secara komprehensif. Agar tercipta kinerja yang diharapkan perusahaan maka pihak manajemen harus dapat menciptakan lingkungan kerja yang kondusif dan peka terhadap kondisi karyawan. Perusahaan juga harus bisa mengatasi masalah-masalah yang sering muncul yang berhubungan dengan kinerja karyawan.

Terdapat banyak faktor yang mempengaruhi kinerja pegawai. Budaya organisasi dan motivasi merupakan bagian dari faktor-faktor yang dapat mempengaruhi terciptanya kinerja karyawan. Budaya organisasi yang tidak kondusif dan motivasi karyawan yang rendah dapat mengakibatkan rendahnya kinerja karyawan yang ada dalam perusahaan.

Setiap individu selalu mempunyai sifat yang berbeda satu dengan yang lainnya. Sifat tersebut dapat menjadi ciri khas bagi seseorang sehingga kita dapat mengetahui bagaimana sifatnya. Sama halnya dengan manusia, organisasi juga mempunyai sifatsifat tertentu. Melalui sifat-sifat tersebut kita juga dapat mengetahui bagaimana karakter dari organisasi tersebut. Sifat tersebut kita kenal dengan budaya organisasi atau organization culture. Budaya-budaya yang dimiliki oleh setiap suku bangsa memiliki sistem nilai dan norma dalam mengatur masing-masing anggotanya dari suku bangsa tersebut maupun orang yang berasal dari suku lain, dengan demikian dapat dikatakan bahwa suatu organisasi juga memiliki budaya yang mengatur bagaimana anggota-anggotanya untuk bertindak.

Budaya memberikan identitas bagi para anggota organisasi dan membangkitkan komitmen terhadap keyakinan dan nilai yang lebih besar dari dirinya sendiri. Meskipun ide-ide ini telah menjadi bagian budaya itu sendiri yang bisa datang di manapun organisasi itu berada. Suatu organisasi budaya berfungsi untuk menghubungkan para anggotanya sehingga mereka tahu bagaimana berinteraksi satu sama lain.

Budaya organisasi merupakan sistem penyebaran kepercayaan dan nilai-nilai yang berkembang dalam suatu organisasi dan mengarahkan perilaku anggota anggotanya. Budaya organisasi dapat menjadi instrumen keunggulan kompetitif yang utama, yaitu bila budaya organisasi mendukung strategi organisasi, dan bila budaya organisasi dapat menjawab atau mengatasi tantangan lingkungan dengan cepat dan tepat.

Selain itu, budaya organisasi membentuk sejumlah fungsi dalam suatu organisasi, yaitu: (1) budaya mempunyai suatu peranan dalam menetapkan tapal batas, artinya budaya menciptakan perbedaan yang jelas antara satu organisasi dengan organisasi yang lain, (2) budaya membawa suatu rasa identitas bagi anggota organisasi, (3) budaya mempermudah timbulnya komitmen pada area yang lebih luas daripada kepentingan individu seseorang, (4) budaya dapat meningkatkan kemantapan sistem, (5) budaya berfungsi sebagai mekanisme pembuatan makna dan kendali yang memandu dan membentuk sikap serta perilaku karyawan.(Robins, 2006b)

Motivasi karyawan dalam organisasi juga sangat penting selain budaya organisasi, karena motivasi yang rendah dapat mempengaruhi kinerja yang rendah pula. Motivasi perlu diketahui oleh setiap pimpinan, setiap orang yang bekerja dengan bantuan orang lain. Motivasi merupakan proses untuk mencoba mempengaruhi seseorang agar melakukan sesuatu yang kita inginkan.(Husnan, 1993)

Sumber motivasi ada tiga faktor, yakni (1) kemungkinan untuk berkembang, (2) jenis pekerjaan, (3) apakah mereka akan merasa bangga menjadi bagian dari perusahaan tempat mereka bekerja. (Veithzal, 2004)

(Maltis, 2002) mengemukakan Motivasi merupakan hasrat di dalam seseorang yang menyebabkan orang 
tersebut melakukan tindakan. Jadi motivasi mempersoalkan bagaimana caranya mengarahkan daya dan potensi bawahan, agar mau bekerja sama secara produktif, berhasil mencapai dan mewujudkan tujuan yang telah ditentukan.

Dorongan pihak manajemen untuk meningkatkan semangat kerja karyawan melalui motivasi untuk mencapai tujuan perusahaan juga sangat diharapkan. Dalam teori motivasi di kemukakan bahwa produktivitas seseorang sangat ditentukan oleh "virus mental" yang ada pada dirinya. Virus mental adalah kondisi jiwa yang mendorong seseorang untuk mampu mencapai prestasi secara maksimal. Motivasi timbul karena adanya motif.

Setiap karyawan akan memiliki motivasi dari motif yang berbeda, untuk itu pihak perusahaan harus mampu memenuhi kebutuhan-kebutuhan dari motif yang berbeda-beda tersebut secara maksimal karena motivasi yang tinggi akan berpengaruh secara positif terhadap kinerja karyawan.

(Soekardi, 2012) meneliti tentang Pengaruh Motivasi Kerja, Budaya Organisasi Dan Kesejahteraan Pegawai Terhadap Kinerja Pegawai Pada Inspektorat Kabupaten Kediri. Hasil penelitian menunjukkan bahwa variabel motivasi kerja, budaya organisasi, dan kesejahteraan mempunyai pengaruh positif yang signifikan terhadap kinerja pegawai (Y). Jadi dapat disimpulkan bahwa Budaya organisasi yang baik dan motivasi kerja yang tinggi akan meningkatkan produktivitas karyawan sehingga berpengaruh pada pencapaian tujuan perusahaan.

\section{Kinerja Pegawai}

Kinerja pegawai adalah yang mempengaruhi seberapa banyak mereka memberi kontribusi kepada organisasi. Perbaikan kinerja baik untuk individu maupun kelompok menjadi pusat perhatian dalam upaya meningkatkan kinerja organisasi, seperti yang diungkapkan oleh (Maltis, 2002).

Menurut (Mangkunegara, 2001) terdapat dua faktor yang mempengaruhi kinerja pegawai adalah a) Faktor Individu, Secara psikologis, individu yang normal adalah individu yang memiliki integritas yang tinggi antara fungsi psikis (rohani) dan fisiknya (jasmaniah). Dengan adanya integritas yang tinggi antara fungsi psikis dan fisik maka individu tersebut memiliki konsentrasi diri yang baik. Konsentrasi yang baik ini merupakan modal utama individu manusia untuk mampu mengelola dan mendayagunakan potensi dirinya secara optimal dalam melaksanakan kegiatan atau aktivitas kerja sehari-hari dalam mencapai tujuan organisasi. b) Faktor Lingkungan Organisasi, Faktor lingkungan kerja organisasi sangat menunjang bagi individu dalam mencapai kinerja. Faktor lingkungan organisasi yang dimaksud antara lain uraian jabatan yang jelas, otoritas yang memadai, target kerja yang menantang, pola komunikasi yang efektif, hubungan kerja yang harmonis, iklim kerja yang respek dan dinamis, peluang berkarir dan fasilitas kerja yang relatif memadai.

(Hasibuan, 2002) Kinerja pegawai dapat dikatakan baik atau dapat dinilai dari beberapa hal, yaitu : 1) Kesetiaan, Kinerja dapat diukur dari kesetiaan pegawai terhadap tugas dan tanggung jawabnya dalam organisasi. kesetiaan adalah tekad dan kesanggupan, menaati, melaksanakan dan mengamalkan sesuatu yang ditaati dengan penuh kesadaran dan tanggung jawab. 2) Prestasi Kerja, Hasil prestasi kerja pegawai, baik kualitas maupun kuantitas dapat menjadi tolak ukur kinerja. Pada umumnya prestasi kerja seorang pegawai dipengaruhi oleh kecakapan, keterampilan, pengalaman, dan kesanggupan pegawai dalam melaksanakan tugas dan fungsinya. 3) Kedisiplinan, Sejauh mana pegawai dapat mematuhi peraturan peraturan yang ada dan melaksanakan instruksi yang diberikan kepadanya. 4) Kreatifitas, Merupakan kemampuan pegawai dalam mengembangkan kreatifitas dan mengeluarkan potensi yang dimiliki dalam menyelesaikan pekerjaannya sehingga bekerja lebih berdaya guna dan berhasil guna. 5) Kerja sama, Dalam hal ini kerja sama diukur dari kemampuan pegawai untuk bekerja sama dengan pegawai lain dalam menyelesaikan suatu tugas yang ditentukan, sehingga hasil pekerjaannya akan semakin baik. 6) Kecakapan, Dapat diukur dari tingkat pendidikan pegawai yang disesuaikan dengan pekerjaan yang menjadi tugasnya. 7) Tanggung jawab, Yaitu kesanggupan seorang pegawai menyelesaikan pekerjaan yang diserahkan kepadanya dengan sebaik-baiknya dan tepat pada waktunya serta berani memikul risiko pekerjaan yang dilakukan.

\section{Budaya Organisasi}

Budaya organisasi merupakan norma, nilai - nilai, asumsi, kepercayaan, filsafat, kebiasaan organisasi, dan sebagainya (isi budaya organisasi) yang dikembangkan dalam waktu yang lama oleh pendiri, pemimpin, dan anggota organisasi yang disosialisasikan dan diajarkan kepada anggota baru serta diterapkan dalam aktivitas organisasi sehingga berpengaruh pada pola pikir, sikap, dan perilaku anggota organisasi dalam memproduksi produk, melayani para konsumen, dan mencapai tujuan organisasi (Wirawan., 2007).

Ada perbedaan antara nilai dan sikap, nilai (value) ialah preferensi terhadap benda-benda, gagasangagasan, orang-orang, lembaga dan pranata, serta perilaku yang mempunyai dasar kultural. Sedangkan sikap (attitude) adalah organisasi (penataan) kepercayaan/ pandangan mengenai hal-ikhwal "di luar diri", yakni kecenderungan untuk berperilaku 
tertentu terhadap obyek atau referen sikap, maka nilai mengungkapkan preferensi dalam hal cara pelaksanaan dan tujuan akhir eksistensi.

Budaya organisasi merupakan suatu sistem dari kepercayaan-kepercayaan dan nilai-nilai bersama dalam organisasi dan mengarahkan perilaku anggotanya. Budaya korporat, atau juga dikenal dengan istilah budaya kerja, merupakan nilai-nilai dominan yang disebarluaskan di dalam organisasi dan diacu sebagai filosofi kerja karyawan.

Menurut pendapat (Moeljono, 2003) budaya korporat mengacu ke suatu sistem makna bersama yang dianut anggota-anggota yang membedakan organisasi itu terhadap organisasi-organisasi lain.

Oleh karena itu tidaklah berlebihan apabila Kreitner dan Kinicki pada bukunya (Kreitner, 2005) mendefinisikan budaya korporat sebagai perekat organisasi melalui nilai-nilai yang ditaati, peralatan simbolis dan cita-cita sosial yang ingin dicapai. Sementara itu, Moeljono (Moeljono, 2003) dengan mengartikan budaya korporat sebagai sistem nilainilai, keyakinan, dan kebiasaan bersama dalam organisasi yang berinteraksi dengan struktur formal untuk menghasilkan norma perilaku. Dapat juga diartikan bahwa budaya korporat merupakan sebuah sistem informasi untuk mempertahankan dan mentransmisikan pengetahuan, kepercayaan, mitosmitos dan tingkah laku.

Berdasarkan pada penjelasan tentang teori sikap dan budaya organisasi, maka dapat ditarik sebuah pengertian dasar tentang sikap pada budaya organisasi. Artinya konsep budaya organisasi menjadi obyek dari sikap. Definisi dari sikap pada budaya organisasi adalah sebagai derajat afeksi positif atau afeksi negatif terhadap budaya organisasi (berupa sistem nilai-nilai, keyakinan, dan kebiasaan bersama dalam organisasi yang berinteraksi dengan struktur formal untuk menghasilkan norma perilaku).

Dalam kehidupan sehari-hari seseorang tidak akan terlepas dari lingkungannya kepribadian seseorang akan dibentuk oleh lingkungan dan agar Kepribadian tersebut mengarah kepada sikap dan perilaku yang positif tentunya harus didukung norma yang diakui tentang kebenarannya dan dipatuhi sebagai pedoman dalam bertindak. Pada dasarnya seseorang yang berada dalam kehidupan organisasi berusaha untuk menentukan dan membentuk sesuatu yang dapat mengakomodasi kepentingan semua pihak, agar dalam menjalankan aktivitasnya tidak berbenturan dengan berbagai sikap dan perilaku dari masingmasing individu. Sesuatu yang dimaksud tidak lain adalah budaya di mana individu berasal seperti nilai, keyakinan, anggapan, harapan dan sebagainya. Budaya juga merupakan faktor yang membentuk sikap dan tingkah laku seseorang.

\section{METODOLOGI PENELITIAN}

Penelitian yang dilakukan merupakan penelitian kausal komparatif, yaitu penelitian yang bertujuan untuk mengetahui kemungkinan adanya hubungan sebab akibat dengan cara tertentu berdasarkan atas pengamatan terhadap akibat yang ada, kemudian mencari faktor yang diduga menjadi penyebabnya, melalui pengumpulan data dengan melakukan perbandingan di antara data yang terkumpul/diteliti. (Murti Sumarni, 2006)

Lokasi penelitiannya pada Yayasan Dompet Dhuafa Republika dengan alamat Perkantoran Ciputat Indah Permai Blok C 28-29 Jl. Ir. H. Juanda No.50, Ciputat Telepon 0217416050 Fax: +62 217416070 , adapun waktu penelitian dimulai dari bulan desember 2013- Juni 2014

Populasi dalam penelitian ini adalah seluruh pegawai kantor pusat dompet dhuafa. Yang berjumlah lebih dari 50 dan kurang dari 300 orang.

Menurut (Sugiyono, 2004) "sampel adalah bagian dari populasi dan memiliki karakteristik yang sama dengan populasi”. Bila tidak memungkinkan bagi peneliti untuk meneliti seluruh populasi tersebut karena keterbatasan dana, tenaga, dan waktu maka peneliti dapat menggunakan sampel, yaitu sebagian dari populasi sehingga kesimpulan yang diperoleh dari sampel itu, akan berlaku juga untuk populasi. Sampel yang diambil dari penelitian ini adalah dengan mengambil dari populasi pegawai yang ada dan setiap sampel akan mewakili departemen atau bagian yang ada dalam tempat penelitian tersebut.

Dalam teknik pengambilan sampel, Menurut Roscoe (1975) yang dikutip (Sekaran. Uma., 2006) memberikan acuan umum untuk menentukan ukuran sampel:

1. Ukuran sampel 30 - 500 adalah tepat untuk kebanyakan penelitian

2. Jika sampel dipecah ke dalam sub sampel (pria/wanita, junior/senior, dan sebagainya), ukuran sampel minimum 30 untuk tiap kategori adalah tepat

3. Dalam penelitian mutivariate (termasuk analisis regresi berganda), ukuran sampel sebaiknya 10x lebih besar dari jumlah variabel dalam penelitian

4. Untuk penelitian eksperimental sederhana dengan kontrol eksperimen yang ketat, penelitian yang sukses adalah mungkin dengan ukuran sampel kecil antara $10-20$

Sampel menurut (Sudjana, 2002) adalah sebagian yang diambil dari populasi. Sampel harus dilakukan dengan benar dan mengikuti cara-cara yang dapat dipertanggungjawabkan agar kesimpulannya dapat dipercaya. Dengan kata lain, sampel itu harus 
representatif dalam arti segala karakteristik populasi hendaknya tercermin pula dalam sampel yang diambil. Teknik pengambilan sampel dengan menggunakan menggunakan rumus Slovin dalam Suliyanto (2006:100) sebagai berikut:

$$
\mathrm{n}=\frac{\mathrm{N}}{1+\mathrm{Ne}^{2}}
$$

Dimana :

$$
0,03 ; 0,04 ; 0,05 \mathrm{dsb})
$$

$$
\begin{array}{ll}
\mathrm{n} & =\text { ukuran sampel } \\
\mathrm{N} & =\text { ukuran populasi } \\
\mathrm{e} & =\text { Margin Kesalahan }(0,01 ; 0,02 ;
\end{array}
$$

Adapun Isaac dan Michael merumuskan tabel penarikan sampel tingkat kesalahan 1\%, 5\%, dan $10 \%$. Jika populasi melebihi angka yang ada dalam tabel. Dalam penarikan sampel, peneliti juga memperhatikan sampel yang akan digunakan untuk menguji coba instrument.

Oleh karena itu, jumlah sampel sebanyak pegawai kantor pusat dompet dhuafa dengan jumlah 50 responden.

\section{Kerangka Berpikir dan Hipotesis}

\section{Budaya organisasi berpengaruh terhadap kinerja.}

Karyawan secara konstan dikelilingi oleh budaya organisasi. Budaya Organisasi membentuk latar belakang yang berkaitan dengan lingkungan, kondisi kerja, sikap, perilaku, serta persepsi karyawan pada organisasi tempat mereka bekerja. Behavior atau perilaku merupakan bagian dari budaya yang berkaitan dengan kinerja sebab dengan berperilaku seseorang akan dapat memperoleh yang Ia kehendaki dan yang diharapkan.

Menurut Gibson dalam Sutanto (2003), pegawai atau karyawan sebagai penggerak operasi organisasi, jika kinerja pegawai baik, maka kinerja organisasi juga akan meningkat. Banyak faktor yang mempengaruhi kinerja pegawai salah satunya budaya organisasi. Budaya organisasi sebagai persepsi umum yang dimiliki oleh seluruh anggota organisasi, sehingga setiap pegawai yang menjadi anggota organisasi akan mempunyai nilai, keyakinan dan perilaku sesuai dengan organisasi. (Gibson, J.I. Ivanevihch, 1990)

(Robins, 2006) mengungkapkan bahwa budaya organisasi yang kuat diperlukan untuk meningkatkan kepuasan kerja dan kinerja karyawan yang pada akhirnya akan berpengaruh pula pada kinerja organisasi secara keseluruhan. Oleh karena itu, setiap organisasi perlu membentuk budaya organisasi yang kuat. Organisasi perlu menyebarluaskan nilai-nilai utamanya kepada seluruh karyawan. Nilai-nilai itu akan melekat pada setiap anggota organisasi, sehingga budaya organisasi ini akan berdampak pada perilaku dan sikap setiap anggota organisasi.

Berdasarkan penelitian yang dilakukan Kottler dan Hesket pada tahun 1992 (Lako, 2004) terhadap suatu organisasi dengan berbagai jenis industri di Amerika Serikat menunjukkan bahwa budaya organisasi berpengaruh positif terhadap peningkatan kinerja dalam jangka panjang.

Jadi Budaya organisasi yang kuat akan membantu organisasi dalam memberikan kepastian kepada seluruh pegawai untuk berkembang bersama, tumbuh dan berkembangnya instansi. Pemahaman tentang budaya organisasi perlu ditanamkan sejak dini kepada pegawai. Bila pada waktu permulaan masuk kerja, mereka masuk ke instansi dengan berbagai karakteristik dan harapan yang berbeda beda, maka melalui training, orientasi dan penyesuaian diri, pegawai akan menyerap budaya organisasi yang kemudian akan berkembang menjadi budaya kelompok, dan akhirnya diserap sebagai budaya pribadi. Bila proses internalisasi budaya organisasi menjadi budaya pribadi telah berhasil, maka pegawai akan merasa identik dengan instansinya, merasa menyatu dan tidak ada halangan untuk mencapai kinerja yang optimal. Ini adalah kondisi yang saling menguntungkan, baik bagi instansi maupun pegawai.

\section{Motivasi berpengaruh terhadap kinerja.}

Motivasi pada dasarnya adalah proses yang menentukan seberapa banyak usaha yang akan dicurahkan untuk melaksanakan pekerjaan. Motivasi atau dorongan untuk bekerja ini sangat menentukan bagi tercapainya sesuatu tujuan, maka manusia harus dapat menumbuhkan motivasi kerja setinggi tingginya bagi para karyawan dalam perusahaan.

Ada hubungan yang positif antara motivasi berprestasi dan pencapaian prestasi. Artinya manajer yang mempunyai motivasi berprestasi tinggi cenderung memiliki prestasi kerja yang tinggi, dan sebaliknya jika mereka yang prestasi kerjanya rendah dimungkinkan karena motivasi berprestasi yang rendah

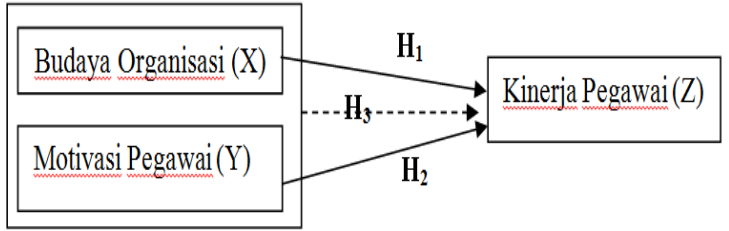

Gambar 1. Hubungan antar variabel

Hipotesis adalah pernyataan sementara yang menghubungkan dua variabel atau lebih. Kesimpulan yang tarafnya rendah karena masih 
membutuhkan pengujian secara empiris(Sugiyono, 2004). Berdasarkan uraian pada kerangka pemikiran di atas , maka penulis dapat merumuskan suatu hipotesis sebagai berikut :

a. Suatu perusahaan akan membutuhkan karyawan atau pegawai yang dapat menyatuakan atau mensintesiskan budaya perusahaan menjadi budaya pribadi para pegawainya, sehingga karyawan akan merasa identik dengan instansinya, merasa menyatu dan tidak ada halangan untuk mencapai kinerja yang optimal. Jadi $\left(\mathrm{H}_{1}\right)$ : Diduga variabel Budaya Organisasi $\left(\mathrm{X}_{1}\right)$ berpengaruh terhadap Kinerja Pegawai $(\mathrm{Y})$

b. Motivasi atau dorongan untuk bekerja ini sangat menentukan bagi tercapainya suatu tujuan, maka manusia harus dapat menumbuhkan motivasi kerja setinggi tingginya bagi karyawan dalam perusahaan. Jadi $\left(\mathrm{H}_{2}\right)$ : Diduga variabel Motivasi Kerja $\left(\mathrm{X}_{2}\right)$ berpengaruh terhadap Kinerja Pegawai (Y).

c. Adanya penelitian terdahulu yang menyimpulkan bahwa pengaruh budaya organisasi dan motivasi terhadap kinerja pegawai pada suatu organisasi atau lembaga, instansi perusahaan, sangat signifikan, Jadi $\left(\mathrm{H}_{3}\right)$ : diduga Budaya Organisasi $\left(\mathrm{X}_{1}\right)$ dan Motivasi Kerja $\left(\mathrm{X}_{2}\right)$ berpengaruh terhadap Kinerja Pegawai (Y).

\section{HASIL DAN PEMBAHASAN}

\section{Hasil Uji Validitas}

Untuk mengetahui suatu instrumen dikatakan valid, yaitu dengan membandingkan koefisien korelasi product moment dengan taraf signifikansi sebesar $\alpha$ $=0,05(5 \%)$ dan membandingkan nilai $\mathrm{r}$ hitung dengan nilai $\mathrm{r}$ tabel (kritis) yang bernilai $=0,279$. Jika signifikansi hasil korelasi kurang dari 0,05 dan nilai $\mathrm{r}$ hitung $\geq \mathrm{r}$ tabel, maka butir pernyataan tersebut dinyatakan valid dan begitu pula sebaliknya.

Tabel 1. Uji Validitas variabel Budaya Organisasi $\left(\mathrm{X}_{1}\right)$

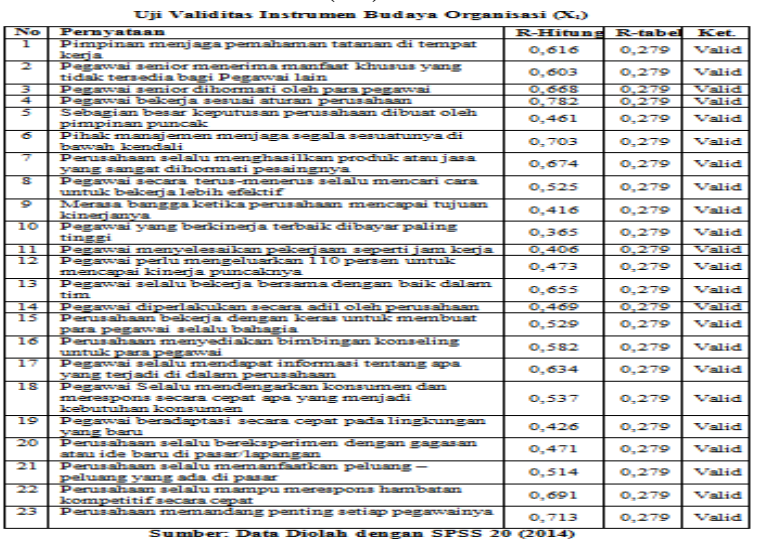

Hasil Uji Validitas dari pernyataan variabel Budaya Organisasi $\left(\mathrm{X}_{1}\right)$ pada kuesioner menunjukkan bahwa r-hitung > r-tabel untuk keseluruhan pernyataan, maka dapat diambil kesimpulan bahwa semua butir pernyataan adalah valid.

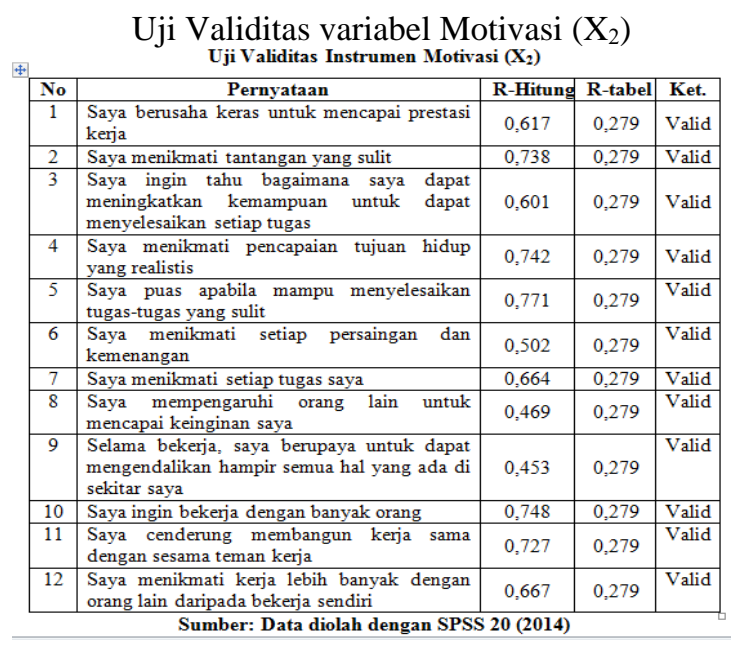

Hasil Uji Validitas dari pernyataan - pernyataan variabel Motivasi $\left(\mathrm{X}_{2}\right)$ pada kuesioner menunjukkan bahwa r-hitung > r-tabel untuk keseluruhan pernyataan, maka dapat diambil kesimpulan bahwa semua butir pernyataan adalah valid.

Tabel 2. Uji Validitas Variabel Kinerja (Y) Uji Validitas Instrumen Kinerja (Y)

\begin{tabular}{|c|l|c|c|c|}
\hline \multicolumn{7}{|c|}{ Uji Validitas Instrumen Kinerja (Y) } \\
\hline No & \multicolumn{1}{|c|}{ Pernyataan } & R-Hitung & R-tabel & Ket. \\
\hline 1 & Tingkat produktivitas pegawai tinggi & 0,653 & 0,279 & Valid \\
\hline 2 & Tingkat kualitas keja pegawai tinggi & 0,722 & 0,279 & Valid \\
\hline 3 & $\begin{array}{l}\text { Tingkat pengetahuan pegawai tentang pekerjaan } \\
\text { tinggi }\end{array}$ & 0,735 & 0,279 & Valid \\
\hline 4 & $\begin{array}{l}\text { Pegawai memiliki keja sama yang baik di } \\
\text { dalam bekerja }\end{array}$ & 0,714 & 0,279 & Valid \\
\hline 5 & $\begin{array}{l}\text { Pegawai menyelesaikan pekerjaan tepat pada } \\
\text { waktunya }\end{array}$ & 0,703 & 0,279 & Valid \\
\hline 6 & $\begin{array}{l}\text { Pegawai memiliki sikap disiplin yang tinggi } \\
\text { terhadap pekerjaan }\end{array}$ & 0,833 & 0,279 & Valid \\
\hline 7 & $\begin{array}{l}\text { Pegawai memiliki inisiatif terhadap } \\
\text { penyelesaian pekejaan }\end{array}$ & 0,667 & 0,279 & Valid \\
\hline 8 & $\begin{array}{l}\text { Pegawai memiliki kemampuan atau ketrampilan } \\
\text { teknis yang tinggi }\end{array}$ & 0,618 & 0,279 & Valid \\
\hline 9 & $\begin{array}{l}\text { Pegawai memiliki kemampuan untuk } \\
\text { menyelesaikan masalahnya sendiri }\end{array}$ & 0,690 & 0,279 & Valid \\
\hline 10 & $\begin{array}{l}\text { Pegawai memiliki kemampuan komunikasi yang } \\
\text { baik antara sesama pegawai maupun dengan } \\
\text { atasan }\end{array}$ & 0,784 & 0,279 & Valid \\
\hline 11 & $\begin{array}{l}\text { Pegawai memiliki kreatifitas yang tinggi } \\
\text { Sumber: Data diolah dengan SPSS 20 (2014) }\end{array}$ & 0,279 & Valid \\
\hline
\end{tabular}

Hasil Uji Validitas dari pernyataan - pernyataan variabel Kinerja (Y) pada kuesioner menunjukkan bahwa r-hitung > r-tabel untuk keseluruhan pernyataan, maka dapat diambil kesimpulan bahwa semua butir pernyataan adalah valid.

\section{Hasil Uji Reliabilitas}

Untuk menguji reliabilitas instrumen digunakan koefisien reliability Alpha Cronbach's yang perhitungannya menggunakan prosedur reliabilitas dengan program SPSS for Windows Ver.20,0.

Tujuannya adalah untuk menilai kestabilan ukuran dan konsistensi responden dalam menjawab kuesioner. Jika nilai cronbach alpha lebih besar dari 0,60 maka kuesioner dapat dikatakan dapat memenuhi konsep reliabilitas. Sedangkan jika nilai cronbach alpha lebih kecil dari 0,60 maka kuesioner tidak memenuhi konsep reliabilitas sehingga pernyataan tidak dapat dijadikan sebagai alat ukur penelitian. Dari hasil uji reliabilitas diperoleh nilai apha di bawah ini: 
Tabel 3.

Hasil Uji Reliabilitas Variabel Budaya Organisasi $\left(\mathbf{X}_{1}\right)$

\begin{tabular}{|r|r|}
\hline \multicolumn{2}{|c|}{ Reliability Statistics } \\
\hline Cronbach's Alpha & N of Items \\
\hline .901 & 23 \\
\hline
\end{tabular}

Sumber: Data diolah dengan SPSS 20 (2014)

Dari 23 pernyataan kuesioner yang disebarkan kepada 50 responden untuk variabel Budaya Organisasi $\left(\mathrm{X}_{1}\right)$, diperoleh nilai Cronbach's Alpha sebesar 0,901. Angka ini berada di atas 0,60. Dengan demikian berarti bahwa item pernyataan untuk semua variabel $\mathrm{X}_{1}$ dinyatakan reliabel.

\section{Tabel 4.}

Hasil Uji Reliabilitas Variabel Motivasi $\left(\mathbf{X}_{2}\right)$

\begin{tabular}{|r|r|}
\hline \multicolumn{2}{|c|}{ Reliability Statistics } \\
\hline Cronbach's Alpha & N of Items \\
\hline .871 & 12 \\
\hline
\end{tabular}

Sumber: Data diolah dengan SPSS 20 (2014)

Dari 12 pernyataan kuesioner yang disebarkan kepada 50 responden untuk variabel Motivasi $\left(\mathrm{X}_{2}\right)$ diperoleh nilai Cronbach's Alpha sebesar 0,871. Angka ini berada di atas 0,60. Dengan demikian item pernyataan untuk seluruh variabel percaya diri $\left(\mathrm{X}_{2}\right)$ dinyatakan reliabel.

Tabel 5.

4.1.1

Hasil Uji Reliabilitas Variabel Kinerja (Y)

\subsection{2}

\begin{tabular}{|r|r|}
\hline \multicolumn{2}{|c|}{ Reliability Statistics } \\
\hline Cronbach's Alpha & N of Items \\
\hline .897 & 11 \\
\hline
\end{tabular}

Sumber: Data diolah dengan SPSS 20 (2014)

Dari 11 pernyataan kuesioner yang disebarkan kepada 50 responden untuk variabel Kinerja (Y) diperoleh nilai Cronbach's Alpha sebesar 0,897. Angka ini berada di atas 0,60. Dengan demikian item pernyataan untuk seluruh variabel Kinerja (Y) dinyatakan reliabel.

\section{Teknik Analisis Data}

Dengan perhitungan regresi linier berganda digunakan untuk memprediksi besarnya hubungan antara variabel terikat (dependen) yaitu Kinerja (Y), dengan variabel bebas (independen) yaitu Budaya Organisasi $\left(\mathrm{X}_{1}\right)$, Motivasi $\left(\mathrm{X}_{2}\right)$. Hasil regresi linier berganda dapat dilihat dibawah ini :

Tabel 6.

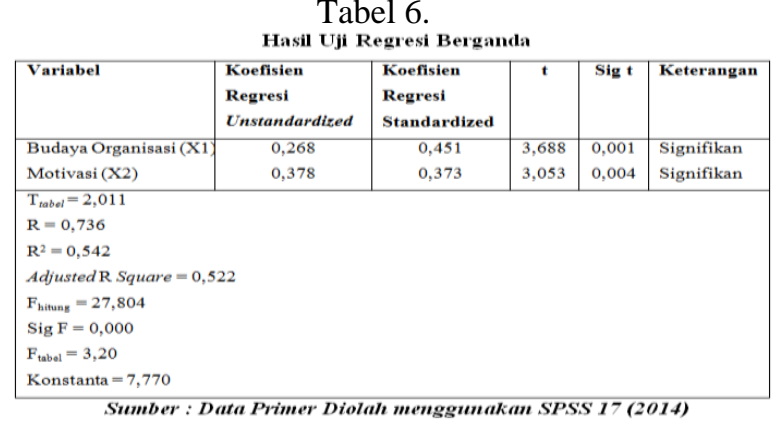

Dan dari hasil pengolahan data diperoleh koefisien regresi dari tabel diatas sebagai berikut :

$Y=7,770+0,268\left(X_{1}\right)+0,378\left(X_{2}\right)$

Dari hasil persamaan regresi diatas maka dapat diketahui bahwa :

a.

b. $\quad \mathbf{Y}=$ Kinerja

Variabel terikat yang nilainya akan diprediksi oleh variabel bebas. Pada penelitian ini yang menjadi variabel terikat adalah Kinerja pegawai dhompet dhuafa, nilainya akan diprediksi oleh variabel Budaya Organisasi $\left(\mathrm{X}_{1}\right)$, dan Motivasi $\left(\mathrm{X}_{2}\right)$.

- $\quad$ Konstanta $=7,770$

Konstanta (a) sebesar 7,770 menyatakan bahwa jika Budaya Organisasi dan motivasi memiliki nilai nol maka Kinerja mempunyai nilai sebesar 7,770.

- $\mathrm{b}_{1}=0,268$

Koefisien regresi $\left(b_{1}\right)$ Sebesar 0,268 dengan tanda positif berarti bahwa semakin baik variabel Budaya Organisasi pegawai maka akan semakin tinggi pengaruhnya terhadap Kinerja pegawai.

- $\mathrm{b}_{2}=0,378$

Koefisien regresi $\left(b_{2}\right)$ sebesar 0,419 dengan tanda positif berarti bahwa semakin baik variabel Motivasi yang dirasakan oleh para pegawai maka akan semakin tinggi pengaruhnya terhadap Kinerja pegawai.

\section{Pengujian Hipotesis F (Uji F)}

Pengujian hipotesis ini yaitu untuk mengetahui pengaruh antara variabel independen (bebas) dengan variabel dependen (terikat). Dalam hipotesis pertama penelitian ini, diduga bahwa seluruh variabel Budaya Organisasi $\left(\mathrm{X}_{1}\right)$, dan variabel Motivasi $\left(\mathrm{X}_{2}\right)$ secara serempak mempengaruhi kepuasan nasabah.

Berdasarkan hasil perhitungan yang dapat dilihat pada tabel diatas, menunjukkan bahwa $\mathrm{F}$ hitung sebesar 27,804 (Signifikansi F =0,000). Jadi $F$ hitung $>\mathrm{F}_{\text {tabel }}(125,325>3,20)$ atau $\mathrm{Sig} \mathrm{F}<5 \%(0,000<$ $0,05)$, dengan demikian Ha diterima dan Ho ditolak yang berarti bahwa secara serempak variabel $\mathrm{X}_{1}, \mathrm{X}_{2}$ mempunyai pengaruh yang signifikan terhadap variabel Y. Jadi terbukti bahwa variabel Budaya Organisasi dan Motivasi berpengaruh secara bersama-sama terhadap Kinerja

Koefisien determinasi berganda $\left(\mathrm{R}^{2}\right)$ digunakan untuk mengetahui besarnya sumbangan atau kontribusi dari keseluruhan variabel bebas pengaruhnya terhadap variabel terikat (Y), sedangkan sisanya dipengaruhi oleh variabel lain yang tidak dimasukkan dalam model.

Berdasarkan Tabel diatas dapat diketahui bahwa koefisien determinasi $\left(\mathrm{R}^{2}\right)$ sebesar 0,542 atau 54,2 $\%$. Artinya variabel $\mathrm{Y}$ dijelaskan sebesar 54,2 \% oleh variabel Budaya Organisasi $\left(\mathrm{X}_{1}\right)$, dan Motivasi $\left(\mathrm{X}_{2}\right)$ sedangkan sisanya sebesar $45,8 \%$ dijelaskan oleh variabel lain yang tidak diteliti dalam penelitian ini. 


\section{Pengujian hipotesis t (uji t)}

Pengujian hipotesis ini untuk mengetahui variabel independen (bebas) manakah yang paling dominan pengaruhnya terhadap Kinerja atas merek Zoya.

Dari hasil Uji t dari tabel diatas menujukkan bahwa terdapat 2 variabel independen $(\mathrm{X})$ mempunyai pengaruh yang signifikan terhadap variabel dependen (Y). Secara rinci dapat dijelaskan sebagai berikut :

\section{Budaya Organisasi $\left(\mathrm{X}_{1}\right)$}

Untuk variabel Budaya Organisasi $\left(\mathrm{X}_{1}\right)$ memiliki

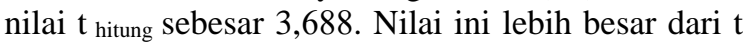
tabel $(3,688>2,011)$ atau Sig $t<5 \%(0,001<0,05)$. Dengan demikian pengujian Ho ditolak dan $\mathrm{Ha}$ diterima. Hal ini memperlihatkan bahwa Budaya Organisasi $\left(\mathrm{X}_{1}\right)$ berpengaruh signifikan terhadap Kinerja (Y).

\section{Motivasi $\left(\mathrm{X}_{2}\right)$}

Untuk variabel Motivasi $\left(\mathrm{X}_{2}\right)$ memiliki nilai $\mathrm{t}_{\text {hitung }}$ sebesar 3,053. Nilai ini lebih besar dari $\mathrm{t}_{\text {tabel }}(3,053\rangle$ $2,011)$ atau Sig $\mathrm{t}<5 \%(0,004<0,05)$. Dengan demikian pengujian Ho ditolak dan Ha diterima. Hal ini memperlihatkan bahwa Motivasi $\left(\mathrm{X}_{2}\right)$ berpengaruh signifikan terhadap Kinerja (Y).

Jadi kesimpulan yang dapat diambil berdasarkan pengujian hipotesis diatas adalah variabel Budaya Organisasi dan Motivasi berpengaruh secara parsial terhadap Kinerja pegawai.

Dari koefisien regresi standardized (Beta) pada tabel diatas variabel Budaya Organisasi mempunyai nilai Beta sebesar 0,451. Sedangkan untuk nilai Beta untuk variabel Motivasi sebesar 0,373. Jadi, dapat ditarik kesimpulan bahwa variabel yang dominan berpengaruh terhadap Kinerja adalah variabel Budaya Organisasi karena memiliki nilai Beta yang tertinggi dari variabel yang lain yaitu sebesar 0,451 .

\section{Uji Asumsi Klasik Regresi}

Setelah melakukan pengujian validitas dan reliabilitas untuk semua instrumen penelitian, maka langkah selanjutnya adalah menyusun persamaan regresi yang berhubungan dengan penelitian. Setiap persamaan yang dihasilkan harus memenuhi syarat asumsi klasik dari persamaan regresi yaitu persamaan regresi yang bersifat BLUE (Best Linier Unbiased Estimated). Uji asumsi klasik yang dilakukan adalah uji multikoliniaritas, uji heterokedastisitas dan uji normalitas.

\section{Uji Multikolinearitas}

Tujuan uji asumsi multikolinearitas adalah untuk menguji apakah model regresi ditemukan adanya korelasi antar variabel independen. Untuk mendeteksi ada tidaknya gejala multikolinearitas maka dilakukan dengan melihat Variance Inflation Factor (VIF), bila nila VIF lebih kecil dari 5 maka tidak terjadi multikolinieritas.

Tabel 7.

Hasil Uji Multikolinearitas

\begin{tabular}{|c|c|l|}
\hline Variabel & $\boldsymbol{V I F}$ & Keterangan \\
\hline Budaya Organisasi $\left(\mathrm{X}_{1}\right)$ & 1,535 & Non Multikolinieritas \\
\hline Motivasi $\left(\mathrm{X}_{2}\right)$ & 1,535 & Non Multikolinieritas \\
\hline
\end{tabular}

Sumber: Data Primer Diolah (2014)

Berdasarkan Tabel diatas diketahui bahwa diantara variabel-variabel bebas yang digunakan mempunyai nilai VIF lebih kecil dari 5, dari hasil tersebut dapat disimpulkan bahwa model regresi linier tersebut bebas dari multikolinearitas atau tidak terjadi korelasi diantara satu dengan yang lain.

\section{Uji Heterokedastisitas}

Dalam analisis regresi berganda untuk mendapatkan hasil yang baik selain tidak terjadi multikolinearitas, maka varians dalam komponen pengganggunya harus sama (homokedastisitas). Jika asumsi ini tidak bisa dipenuhi maka terjadi heterokedastisitas.

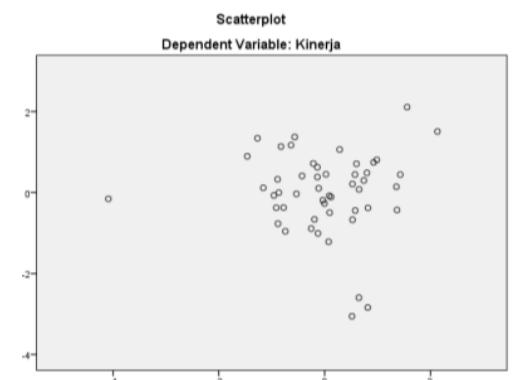

\section{Gambar 2. Grafik Uji Heterokedastisitas}

Adapun pedomannya dengan melihat pola tertentu pada grafik heterokedastisitas diatas. Dasar pengambilan keputusannya sebagai berikut:

1. Jika ada pola tertentu seperti titik-titik (pointpont) yang ada membentuk suatu pola tertentu yang teratur (bergelombang, melebar kemudian menyempit), maka terjadi heterokedastisitas.

2. Jika tidak ada pola yang jelas, serta titik-titik menyebar diatas dan dibawah angka pada sumbu Y, maka tidak terjadi heterokedastistas.

Dari Gambar diatas terlihat bahwa titik-titik menyebar secara acak tidak membentuk pola tertentu yang jelas, seperti bergelombang, melebar kemudian menyempit. Selain itu titik-titik tersebut menyebar diatas dan dibawah angka pada sumbu Y, maka dapat disimpulkan bahwa tidak terjadi heterokedastisitas.

\section{Uji Normalitas}

Untuk menguji apakah dalam model regresi, variabel dependen (terikat) dan variabel independen (bebas) keduanya mempunyai distribusi normal dapat dilihat pada grafik Histogram maupun grafik normal P-P Plot. 
Distribusi data haruslah normal atau mendekati normal untuk memenuhi asumsi normalitas. Dasar pengambilan keputusannya adalah sebagai berikut:

1. Jika data menyebar di sekitar garis diagonal dan mengikuti arah garis diagonal, maka model regresi memenuhi asumsi normalitas.

2. Jika data menyebar jauh dari garis diagonal dan atau tidak mengikuti arah garis diagonal, maka model regresi tidak memenuhi asumsi normalitas.

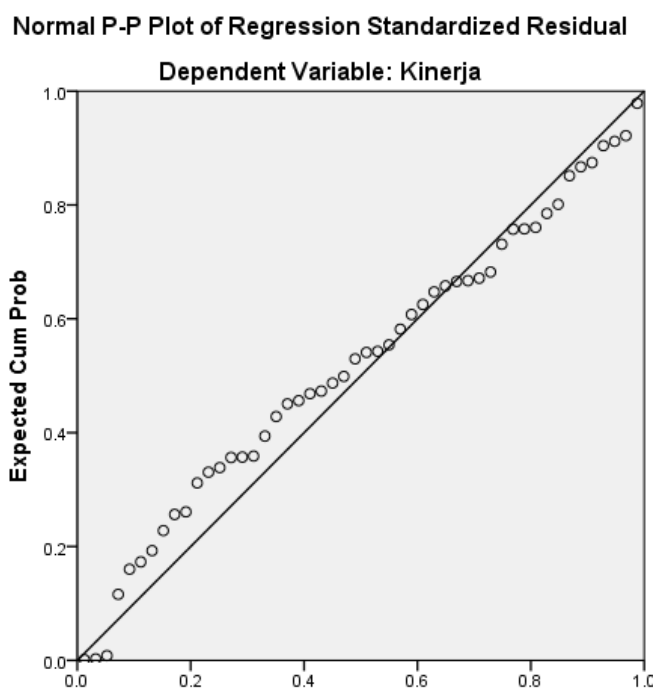

Gambar 3. Grafik Uji Normalitas

Dari Gambar diatas dapat dilihat bahwa adanya titik-titik yang menyebar dan disekitar garis diagonal serta penyebarannyapun mengikuti arah garis diagonal. Hal tersebut membuktikan bahwa model regresinya telah memenuhi asumsi normalitas.

Dari hasil penelitian terlihat bahwa seluruh variabel bebas (budaya organisasi dan motivasi mempunyai pengaruh terhadap kinerja pegawai. Dan variabel yang dominan adalah budaya organisasi. Jadi perusahaan harus memperhatikan budaya organisasi dan motivasi dari para pegawainya.

Budaya organisasi sangat penting bagi para pegawai karena dengan budaya organisasi yang kuat akan membantu organisasi dalam memberikan kepastian kepada seluruh pegawai untuk berkembang bersama, tumbuh dan berkembangnya instansi. Selain itu budaya organisasi akan memacu kinerja para pegawainya. Jika budaya organisasinya meningkat maka kinerjanya akan semakin baik begitu pula sebaliknya.

Motivasi juga sangat penting bagi para pegawai karena Motivasi pada dasarnya adalah proses yang menentukan seberapa banyak usaha yang akan dicurahkan untuk melaksanakan pekerjaan". Motivasi atau dorongan untuk bekerja ini sangat menentukan bagi tercapainya sesuatu tujuan, maka manusia harus dapat menumbuhkan motivasi kerja setinggi tingginya bagi para karyawan dalam perusahaan. Dan jika motivasi para pegawai meningkat maka kinerjanya juga akan semakin meningkat. Kesimpulan hasil akhir dapat dilihat pada tabel berikut ini :

Tabel 8. Hasil akhir penelitian

Hasil Akhir Penelitian

Coefficients $^{\mathrm{a}}$

\begin{tabular}{|c|c|c|c|c|c|c|}
\hline \multirow{2}{*}{\multicolumn{2}{|c|}{ Model }} & \multicolumn{2}{|c|}{ Unstandardized Coefficients } & \multirow{2}{*}{$\begin{array}{c}\text { Standardized } \\
\text { Coefficients }\end{array}$} & \multirow[t]{2}{*}{$\mathrm{t}$} & \multirow[t]{2}{*}{ Sig. } \\
\hline & & B & Std. Error & & & \\
\hline \multirow{3}{*}{1} & (Constant) & 7.770 & 5.305 & & 1.465 & .150 \\
\hline & Budaya Organisasi & .268 & .073 & .451 & 3.688 & .001 \\
\hline & Motivasi & .378 & .124 & .373 & 3.053 & .004 \\
\hline
\end{tabular}

. Dependent Variable: Kinerja

\begin{tabular}{|ll|r|r|r|c|c|}
\hline \multicolumn{1}{|c|}{ Model $^{\text {MNA }} \mathbf{A}^{\mathbf{a}}$} \\
\hline \multirow{4}{*}{1} & Regression & Sum of Squares & \multicolumn{1}{c|}{ df } & Mean Square & F & \multicolumn{1}{c|}{ Sig. } \\
\hline & Residual & 1290.579 & 2 & 645.290 & 27.804 & $\mathbf{. 0 0 0}^{\text {b }}$ \\
& Total & 1090.782 & 47 & 23.208 & & \\
\hline
\end{tabular}

a. Dependent Variable: Kinerja

b. Predictors: (Constant), Motivasi, Budaya Organisasi

\begin{tabular}{|l|l|r|r|r|}
\multicolumn{5}{|c|}{ Model Summary ${ }^{\mathrm{b}}$} \\
\hline Model & \multicolumn{1}{|c|}{ R } & R Square & Adjusted R Square & Std. Error of the Estimate \\
\hline 1 &. $\mathbf{7 3 6}$ & $\mathbf{. 5 4 2}$ & .522 & 4.81748 \\
\hline
\end{tabular}

a. Predictors: (Constant), Motivasi, Budaya Organisasi

b. Dependent Variable: Kinerja

Dari table Coefficients diatas, diketahui bahwa secara parsial variable budaya organisasi berpengaruh terhadap kinerja, dilihat dari nilai signifikansi $0,01<$ sig. 0,05 dan besarnya pengaruh dilihat dari nilai standardized coefficients Beta sebesar 0,451 atau 45,1\%. Secara parsial variable Motivasi berpengaruh terhadap kinerja, dilihat dari nilai signifikansi $0,04<$ sig. 0,05 dan besarnya pengaruh dilihat dari nilai standardized Coefficients Beta sebesar 0,373 atau 37,3\%.

Dari table Annova diatas, diketahui bahwa secara simultan atau bersama-sama variable budaya organisasi dan motivasi berpengaruh terhadap kinerja, dilihat dari nilai signifikansi $0,00<$ sig. 0,05 .

Dari Tabel Model Summary diatas, dapat diketahui bahwa koefisien determinasi $\left(\mathrm{R}^{2}\right)$ sebesar 0,542 atau $54,2 \%$. Artinya variabel $\mathrm{Y}$ dijelaskan sebesar 54,2 $\%$ oleh variabel Budaya Organisasi $\left(\mathrm{X}_{1}\right)$, dan Motivasi $\left(\mathrm{X}_{2}\right)$ sedangkan sisanya sebesar $45,8 \%$ dijelaskan oleh variabel lain yang tidak diteliti dalam penelitian ini.

\section{KESIMPULAN}

Berdasarkan hasil analisis dan pembahasan mengenai pengaruh budaya organisasi dan motivasi terhadap kinerja yayasan dompet dhuafa, maka dapat ditarik kesimpulan sebagai berikut:

1. Variabel budaya organisasi $\left(\mathrm{X}_{1}\right)$ dan motivasi $\left(\mathrm{X}_{2}\right)$ berpengaruh secara simultan atau bersamasama dan signifikan terhadap kinerja karyawan yayasan dompet dhuafa. 
2. Variabel Budaya organisasi $\left(\mathrm{X}_{1}\right)$ dan motivasi $\left(\mathrm{X}_{2}\right)$ mempunyai pengaruh secara parsial dan signifikan terhadap kinerja dompet dhuafa dengan arah hubungan positif atau sifat hubungan searah.

3. Variabel budaya organisasi $\left(\mathrm{X}_{1}\right)$ mempunyai pengaruh dominan terhadap kinerja dompet dhuafa.

\section{REFERENSI}

Gibson, J.I. Ivanevihch, dan D. (1990). Perilaku Organisasi: Struktur Proses. Jakarta: Bina Rupa Aksara.

Hasibuan, M. (2002). Manajemen Sumber Daya Manusia (Edisi Revi). Jakarta: Bumi Aksara.

Husnan, S. dan H. (1993). Manajemen Personalia (Edisi Keem). Yogyakarta: BPFE.

Kreitner, R. dan K. (2005). Perilaku Organisasi (Edisi Terj). Jakarta: Salemba Empat.

Lako, A. (2004). Kepemimpinan dan Kinerja Organisasi Isu Teori dan Solusi. Yogyakarta: Amara Books.

Maltis, L. R. dan J. (2002). Manajemen Sumber Daya Manusia (Buku dua E). Jakarta: Salemba Empat.

Mangkunegara, A. (2001). Manajemen Sumber Daya Manusia Perusahaan. Bandung: PT. Remaja Rosdakarya.

Moeljono, D. (2003). Budaya Korporat dan Keunggulan Korporasi. Jakarta: PT. Elex Media Komputindo.

Murti Sumarni. (2006). Metodologi Penelitian Bisnis. Yogyakarta: ANDI.

Prawirosentono, S. (2008). Manajemen Sumber Daya Manusia (edisi kedu). Yogyakarta: STIE YKPN.
Robins, P. S. (2006a). Perilaku Organisasi, Edisi kesepuluh. Terjemahan Benyamin Molan. Indonesia: PT Indeks Kelompok Gramedia.

Robins, P. S. (2006b). Perilaku Organisasi (Edisi kese). jakarta,Indonesia: PT Indeks Kelompok Gramedia.

Sekaran. Uma. (2006). Metode Penelitian Bisnis. Jakarta: Salemba Empat.

Soekardi, N. (2012). Pengaruh Motivasi Kerja, Budaya Organisasi Dan Kesejahteraan Pegawai Terhadap Kinerja Pegawai Pada Inspektorat Kabupaten Kediri. REVITALISASI. Jurnal Ilmu Manajemen, Vol. 1, No. 3

Sudjana. (2002). Metode Statistika. Bandung: Tarsito.

Sugiyono. (2004). Metode Penelitian Administrasi (edisi keli). Bandung: CV. Alfabeta.

Veithzal, R. (2004). Manajemen Sumber Daya Manusia Untuk Perusahaan Dari Teori ke Praktek. Jakarta: PT. Rajagrafindo.

Wirawan. (2007). Budaya dan iklim organisasi: Teori aplikasi dan penelitian. Jakarta: Salemba Empat.

\section{PROFIL PENULIS}

A.Rafiq lahir di Jakarta pada tahun 1981 dan menyelesaikan pendidikan di Jakarta. Lulus menyelesaikan jenjang Strata 1 jurusan Komunikasi Penyiaran Islam dari Faktutas Agama Islam Universitas Islam Attahiriyah - Jakarta, dan mengambil Strata 2 (Magister Manajemen) dari Universitas BSI-Bandung. Mulai mengajar di Bina Sarana Informatika dari tahun 2011 sampai sekarang 